\title{
Barneperspektiv i nordisk pedagogikk, barne- og ungdomsforskning
}

Senhøstes 2017 arrangerte forskere ved Institutt for pedagogikk og livslang læring og Institutt for lærerutdanning, NTNU, et forskningsseminar om barneperspektiv i pedagogikk-, barne- og ungdomsforskning. Begrepet barneperspektiv ble drøftet ut fra ulike faglige ståsteder, som pedagogikk, filosofi, antropologi og tverrfaglig barneforskning. Bakgrunnen for seminaret var et ønske om å holde levende en diskusjon om hva man kan forstå med barneperspektiv i forskningen - undersøke spørsmål som hvordan syn på barn og barndom endrer seg over tid, hvilke temaer det forskes på, og hvilke teoretiske perspektiver forskningen forholder seg til. Samlet sett ønsket vi med seminaret å undersøke med et kritisk blikk ulike måter å posisjonere barn og barndom på i dag, og på det grunnlaget åpne opp for aktuelle problemstillinger for videre forskning på feltet.

Det historiske bakteppe arrangørene hadde, var et seminar ved Norsk senter for barneforskning tidlig på 1990-tallet, der undertegnede også deltok. Tema for dette seminaret var Hva er et barneperspektiv? Seks forskere ved senteret presenterte hva de la i dette begrepet. Dette var Marianne Gullestad, Anne Trine Kjørholt, Alfred Oftedal Telhaug, Per Olav Tiller, RolfTh. Tønnessen og Eli Åm. Innleggene ble presentert i tidsskriftet BARN (1/1991). Innleggene som finnes der har siden blitt mye diskutert og referert til, og var et av flere bidrag til utviklingen av det som senere fikk benevnelsen The New Sociology of Childhood.

Selv om barns posisjon på mange måter har endret seg mye, så vel i forskning som i samfunnet generelt, er problemstillinger som ble reist for snart 30 år siden høyst relevante også i dag, noe som illustreres av flere artikler i dette temanummeret. Det ble for eksempel etterlyst forskning som brukte barn som sakkyndige informanter samtidig som man understreket etiske dilemmaer, posisjoner og definisjonsmakt knyttet til det å re-presentere verden slik den ser ut for barn. Den respekt og myndiggjøring av barn som ligger implisitt i ideen om «barns egen kultur» ble presentert på dette seminaret som en motkultur til blant annet det som ble oppfattet som den pedagogiske psykologiens iboende instrumentelle og nære kobling til didaktiske imperativer. Samtidig så noen av forskerne en fare i å homogenisere barn, og argumenterte for mange barneperspektiver i stedet for ett. Det ble advart mot en definisjon av «barneperspektivet» 
i bestemt form, som om det skulle være en ensartet størrelse. Noen tok til orde for at voksnes konstruksjoner og intellektuelle begrensning kunne bety en fare for idyllisering i forsøkene på «å ta barns perspektiv». En oppfordring var å gjøre barneperspektiv til gjenstand for kontinuerlig problematisering og drøfting.

Det er nettopp det å løfte frem, problematisere og drøfte et barneperspektiv vi ønsker å giøre med dette temanummeret. Siden begynnelsen av 1990-tallet, har fokus på barns rettigheter hatt betydelig innflytelse på problematiseringer og drøftinger av dette begrepet. Polariserte forestillinger om barn som enten beings eller becomings har dominert mange akademiske tekster. Flere forskere har kritisert denne polariserte ideen, og to vesentlige spørsmål er hvilke ontologiske posisjoner disse ideene bygger på, og hvor de bringer oss i retning av å forstå barneperspektiv i vår tid.

Vi ønsker gjennom dette temanummeret å reise spørsmål om barneperspektiv og barns perspektiver i et endret samfunn - og i nordisk pedagogikk- og barne/ungdomsforskning. For eksempel er dette temaet i Norge aktualisert giennom ny overordnet del av læreplanverket for skolen og ny rammeplan for barnehagens innhold.

I forlengelsen av seminaret i 2017 inviterte vi forskere i Norden til å bidra til dette temanummeret i Nordisk tidsskrift for pedagogikk og kritikk. Vi ønsket artikler - både empiriske og teoretiske - som bidrag til en tverrfaglig, kritisk og kontinuerlig drøfting av begrepet barneperspektiv. Spørsmålene nedenfor var ment som inspirasjon til dette temanummeret og kan forhåpentligvis også fortsette å være til inspirasjon $\mathrm{i}$ forskning på tematikken:

- Hva legger vi i begrepet barneperspektiv i dag?

- Representerer det et nyttig og viktig perspektiv?

- Hvilke sammenhenger kan vi identifisere mellom samfunnsmessige endringer og epistemologier i pedagogikk-, barne- og ungdomsforskning?

- Hvordan posisjoneres barn i forskningen?

- Hvordan påvirker strukturelle endringer, som for eksempel læreplaner, rammeplaner og praksis for skole og barnehage barns liv og didaktisk tilnærming?

- Hvordan forstås og praktiseres det som gjerne kalles rettighetsdiskursen, som siden 1990-tallet hevdes å ha hatt betydelig innflytelse på forestillinger om barn og barndom?

- Hvilke ontologiske posisjoner bygger polariserte ideer om barn som enten beings eller becomings på, og hvor bringer de oss $\mathrm{i}$ retning av å forstå barneperspektiv i vår tid?

- «Å ta barns perspektiv» - hva betyr det?

- Hvordan forholder forskeren seg til sine egne forestillinger og intellektuelle begrensning?

- Hvilke etiske og metodologiske problemstillinger reises ved bruk av barn som informanter eller medforskere? (makt, idyllisering, homogenisering, personvern osv.)

- Hvordan re-presenterer vi barn slik verden ser ut for barn? 
- Ny teknologi gir nye måter å involvere barn i forskningen på. Hvilke problemstillinger trenger gjennomtenkning?

- Hvilke nyskapende teoretiske og filosofiske bidrag til barneperspektiv i pedagogikk og barne/ungdomsforskning finnes?

- Hva kan vi lære om barneperspektiv i forskning med en historisk tilnærming?

I dette nummeret av Nordisk tidsskrift for pedagogikk og kritikk har vi gleden av å presentere syv artikler. De nærmer seg temaets hovedfokus fra ulike vinkler, så vel empirisk som teoretisk. De har likevel et felles omdreiningspunkt knyttet til det å lytte til barn, barns aktørskap, motstand, medvirkning, ut fra empiriske studier, samt mer teoretiske diskusjoner som kan være viktige bidrag inn i den pågående samtalen om barneperspektiv som begrepsmessig overbygning i forskning om pedagogikk, barn og barndom.

God lesning!

Vebjørg Tingstad

Gjesteredaktør

Maria Øksnes

Redaktør 